\title{
Sciendo
}

Administration, vol. 67, no. 1 (2019), pp. 1-6

doi: 10.2478/admin-2019-0001

\section{Political developments, 2018}

\author{
Hugh O'Donnell \\ Institute of Public Administration, Ireland
}

\section{Referendum on the repeal of the Eighth Amendment}

In January 2018 Taoiseach Leo Varadkar, TD, and leader of Fianna Fáil Micheál Martin, TD, both announced their support for the repeal of the Eighth Amendment and for the proposal to allow unrestricted access to abortion up to twelve weeks, the position that had been recommended by the Oireachtas Committee on the Eighth Amendment of the Constitution.

The legislation allowing for the referendum to take place was passed through the Oireachtas on 28 March, with the date for the referendum set for Friday 25 May. This, in effect, marked the beginning of the campaign by both sides although rallies had taken place earlier in the month. An interesting development occurred in relation to online advertising in early May, when Facebook banned all ads related to the referendum from advertisers based outside of Ireland, with Google later banning all ads related to the referendum in their entirety. This move followed increasing concern both internationally and in Ireland about the unregulated nature of online advertising and the influence such ads have on democracy (see Weckler et al., 2018).

The referendum was ultimately passed by a majority of 66 per cent in favour to 34 per cent against on a turnout of just over 64 per cent. The referendum was overwhelmingly approved in urban constituencies; only one constituency, Donegal, had a majority 'No' vote against the referendum. 
At year end the bill that allows for the introduction of abortion services in Ireland had passed all stages of the Houses of the Oireachtas and had been signed into law by President Michael D. Higgins (see Conneely, 2018).

\section{Presidential election and blasphemy referendum}

Ireland's presidential election took place on 26 October. This was only the second time that the incumbent running for re-election had been challenged in a presidential election, the first being Éamon de Valera in 1966. There were six candidates for the position, including three former or current TV personalities from the television series Dragons' Den: former candidate Seán Gallagher, Gavin Duffy and Peter Casey. The other candidates were Senator Joan Freeman, who founded Pieta House, as well as Sinn Féin MEP Liadh Ní Riada and the incumbent, President Michael D. Higgins.

Opinion polls from the outset gave Michael D. Higgins a strong lead. Controversy occurred during the campaign when Peter Casey made disparaging remarks about the travelling community. Ultimately, Michael D. Higgins secured re-election, winning over 55 per cent of the vote on the first count, with Peter Casey coming a distant second with over 23 per cent of first-preference votes. Turnout was very low at less than 44 per cent, down over 12 per cent on the previous presidential election in 2011 (see 'Michael D Higgins reelected', 2018). Michael D. Higgins was sworn in for his second term on 11 November.

A referendum on removing blasphemy from the Constitution was held on the same day as the presidential election. There was a relatively low-key campaign. The Church of Ireland and the Irish Catholic Bishops' Conference had not opposed the removal of blasphemy, with the latter group describing the constitutional provision as 'largely obsolete' (see Gallagher, 2018). Most of the attention was instead focused on the presidential election. On a similar turnout to the presidential election, over 64 per cent voted in favour of removing the reference to blasphemy from the Constitution.

\section{Northern Ireland Assembly}

Ongoing disagreement between the Democratic Unionist Party (DUP) and Sinn Féin in respect of the introduction of legislation on the Irish language has been one of the key sticking points preventing 
the restoration of the power-sharing executive in Northern Ireland. Prime Minister Theresa May and Taoiseach Leo Varadkar seemed optimistic of breaking the impasse and went to Northern Ireland on 12 February to facilitate an agreement. Despite extensive talks, no compromise has been found and Northern Ireland remains without a functioning executive. DUP leader Arlene Foster has repeatedly insisted that the party will not agree to a stand-alone Irish Language Act. The continued impasse has led to increased talk about the reinstatement of direct rule from Westminster. At year end there was still no executive.

\section{No-confidence motion and resignation of Denis Naughten, TD}

In late September Sinn Féin tabled a motion of no confidence in Minister for Housing, Planning and Local Government Eoghan Murphy, TD. In the days leading up to the vote Fine Gael Junior Minister Catherine Byrne, TD, indicated that she might support the motion against her cabinet colleague. After days of uncertainty Deputy Byrne confirmed that she would support Deputy Murphy, and Fianna Fáil indicated that they would abstain as per the terms of their confidence and supply agreement with Fine Gael. Consequently, Deputy Murphy survived the vote by 59 votes to 49 , thus averting a potential political crisis and a potential threat to the survival of the government.

On 11 October Denis Naughten, TD, resigned as Minister for Communications, Climate Action and Environment after the Taoiseach asked him to reflect on his position. The resignation arose after revelations about a number of dinners and meetings between the minister and the head of the only group bidding for the national broadband licence. After the resignation, Richard Bruton, TD, was moved to the Communications, Climate Action and Environment portfolio, with Joe McHugh, TD, promoted to the front bench and becoming the Minister for Education and Skills.

\section{The Charleton Tribunal and a new Garda Commissioner}

In mid October Mr Justice Peter Charleton released his report on the 'Tribunal of Inquiry into protected disclosures made under the Protected Disclosures Act 2014 and certain other matters following Resolutions'. In the report Mr Justice Charleton concluded that 'Sgt McCabe is a genuine person who at all times has had the interests of 
the people of Ireland uppermost in his mind. ... The report ... [also] strongly criticised the child and family agency Tusla for its handling of a false rape claim made against Sgt McCabe' (see 'McCabe says report "hard to take", 2018).

Mr Justice Charleton was critical of Tusla, stating that, in effect, if it were not for Tusla's inability to quickly own up to its errors, there might have been no need for a tribunal at all. The tribunal was particularly scathing of then Garda Commissioner Martin Callinan, with Mr Justice Charleton saying that there was a 'campaign of calumny against Maurice McCabe by Commissioner Martin Callinan and that in it he was actively aided by his press officer, Supt Dave Taylor'. Although it must be noted that the tribunal found 'no credible evidence that [former commissioner] Nóirín O'Sullivan played any hand, act or part in any campaign conducted by' Mr Callinan and Supt Taylor. The former Minister for Justice, Francis Fitzgerald, TD, was exonerated by the tribunal's report, stating that at all times she had acted appropriately.

Former Police Service of Northern Ireland Deputy Chief Constable Drew Harris was appointed as Garda Commissioner and took up his new role in early September. Mr Harris took over from acting Commissioner Dónall Ó Cualáin. In relation to the Charleton Tribunal, Commissioner Harris said An Garda Síochána fully accepted the findings of Mr Justice Charleton (see 'McCabe says report "hard to take", 2018).

\section{Confidence and supply agreement extended}

In mid December Fianna Fáil and Fine Gael announced the extension of the confidence and supply agreement, after numerous talks since the budget in October. Fianna Fáil leader Micheál Martin stated that his party would guarantee that the government could continue throughout 2019, and that an election may be held in the spring of 2020; this decision took account of uncertainties surrounding Brexit.

\section{Economic growth, Budget 2019 and the National Development Plan}

The Irish economy performed strongly in 2018, with the Economic and Social Research Institute forecasting GDP growth at 8.9 per cent in 2018 and unemployment expected to decline to 5.7 per cent in 2018 (see Economic and Social Research Institute, 2018). This strong 
economic performance allowed for a positive budget by Minister for Finance Paschal Donohoe, TD, which focused more on new spending in areas such as housing and health rather than on tax cuts.

The National Planning Framework and National Development Plan were released in February. This locked in spending increases for the years ahead. The National Development Plan set out $€ 116$ billion in investment in the country's infrastructure over a ten-year period.

\section{Other significant political events}

In February Gerry Adams, TD, stood down as the leader of Sinn Féin, with Mary Lou McDonald, TD, replacing him without a leadership vote as she was the sole nominee. This marked the end of thirty-four years of Sinn Féin leadership by Deputy Adams.

On St Patrick's Day, during his visit to Washington DC, Taoiseach Leo Varadkar admitted to intervening on a planning issue on behalf of Donal Trump's Doonbeg Golf Course when he was Minister for Transport, Tourism and Sport. The Taoiseach stated that he had contacted Clare County Council on behalf of Mr Trump. The admission by the Taoiseach led to swift political criticism by the opposition parties in the Oireachtas but after an initial furore, the issue receded.

In June the local electoral area boundary committees published their reports on the review of and changes to the local electoral area (LEA) boundaries used for local elections. The results led to the diminution of the size of many LEAs, with a corresponding increase in the overall number of LEAs.

In late June former Anglo Irish Bank Chief Executive David Drumm was convicted and sentenced to six years in jail for his role in a $€ 7.2$ billion fraud perpetrated in 2008 during his time at the bank.

Also in late June Michael Lowry, TD, was convicted of filing an incorrect tax return and failing to keep proper accounts. Deputy Lowry was fined $€ 15,000$ personally and was also disqualified from acting as a director of a company for three years.

Pope Francis visited Ireland in August as part of the World Meeting of Families 2018. The Pope spent two days visiting Knock, Croke Park and Phoenix Park, where he celebrated mass on his final day. Bad weather contributed to a lower than expected turnout at the mass, with Gardaí estimating that less than 130,000 people arrived despite capacity and expected numbers of 500,000. There were also small protests during the papal visit against clerical child sexual abuse. The issue was acknowledged by Pope Francis during his visit. 


\section{References}

Conneely, A. (2018, December 13). Abortion legislation passes all stages of Oireachtas. Retrieved from https://www.rte.ie/news/politics/2018/1213/ 1016979-politics-abortion-bill/ [19 December 2018].

Economic and Social Research Institute. (2018, September 26). Economic growth revised upward in 2018 and 2019. Retrieved from https://www.esri.ie/ news/economic-growth-revised-upward-in-2018-and-2019/ [19 December 2018].

Gallagher, C. (2018, October 3). Constitutional blasphemy clause 'largely obsolete', Bishops decide. The Irish Times.

McCabe says report 'hard to take' but is happy with its publication (2018, October 12). Retrieved from https://www.rte.ie/news/politics/2018/1011/ 1002457-disclosures-tribunal-report/ [19 December 2018].

Michael D Higgins re-elected for second term at Áras an Uachtaráin. (2018, October 28). Retrieved from https://www.rte.ie/news/presidentialelection/2018/1027/1006998-presidential-election/ [19 December 2018].

Weckler, A., Ewald, K., \& Anderson, N. (2018, May 9). Google and YouTube to ban all ads relating to abortion referendum. The Irish Independent. 